\title{
Implementation of Inquiry Based Learning to Improve Understanding the Concept of Electric Dynamic and Creative Thinking Skills (An empirical study in Class IX Junior High School Students State 4 Kendari)
}

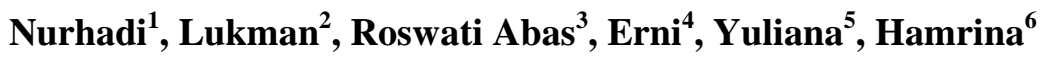 \\ 1, 2, 3, 4, 5, 6 Magister Program Education of Natural Science Halu Oleo University, Kendari, Indonesia
}

\begin{abstract}
This study aims to explain the understanding of the concept and creative thinking skills of students who take the inquirybased learning and conventional, to analyze an improved understanding of concepts and creative thinking skills students on the dynamic electrical material. This research approach is an experiment with the design of "The Randomize pretest-posttest control group" that carried out in grade IX junior high school students 4 Kendari for the school year 2015/2016. Collecting data through instrument (questionnaire) was performed using the initial test and final test for the understanding of the concept and creative thinking skills of students. Results of this study gained an average of $N$-gain students understanding of the concept of 0.49 for the experimental class and 0.22 for control class. As for the data $N$-gain creative thinking skills students 0.70 for the experimental class and 0.31 for control class. Results of hypothesis testing using $t$ test and Mann Whitney $\left(U_{\text {tes }}\right)$ two independent samples showed that an improved understanding of the concepts and creative thinking skills of students who take the inquiry-based learning is higher than students who take conventional learning. Concluded that there are differences in the increase in understanding of the concept and creative thinking skills significantly between students who take the inquiry-based learning and students who take conventional learning.
\end{abstract}

Keywords: Inquiry-Based Learning, Electric Dynamic, Creative Thinking Skills

\section{Introduction}

In the process of learning science, students must have a variety of thinking skills in order to solve problems in everyday life creatively according to its own merits. Thinking skills that can be owned by students when applying inquiry learning. This is in accordance with the opinion of Sanjaya (2011) which states that the inquiry learning is able to develop the ability to think with a systematic, logical, critical, or develop intellectual abilities as part of the mental process. In line with the Ministry of Education (2006) states the process of scientific inquiry aims to foster thinking skills, scholarly work and behave and communicate as one of the important aspects of life skills. During the learning process students should be able to pour and develop creative ideas, not just limited to memorize the concepts that have been given by the teacher.

The low creative thinking skills and understanding of concepts is caused by many factors such as learning methods that are less appropriate to the characteristics of the dynamic electric material, learning classical only cantered on the teacher. McBride (2004) revealed that many students learn just memorize concepts, noting what people talk teacher, passive, and rarely use prior knowledge as a basis for planning learning. As these constraints are too dense material characteristics and benchmarks measuring educational success at school is largely focused on developing the cognitive aspects. Students find it difficult to integrate the concepts associated with coherent framework because students are often trained mathematically to solve a problem. Freedom students in conveying ideas and curiosity only limited to instruction by the teacher, activities exercises, and read only textual modules so that learning becomes meaningless activities.

Especially science inquiry learning process will be meaningful if the learning process is in accordance with the nature of science, which means learning FIPA is not enough just through the collection of facts, principles, laws, and theories, but also about the process of how knowledge is acquired. One way to do is through experimentation. Through experiments, students perform minds on and hands on. Student participation in the activities of the investigation through experiment encourages students to ask questions, propose hypotheses, make predictions, using tools to collect and analyze data, make inferences, building arguments, communicating findings, and use reasoning strategies widely involving critical thinking skills, creative, causal and logical thinking (Olson \& Loucks-Horsley; Minstrell \& Van Zee in Chin \& Chia, 2005).

To develop creative thinking skills more optimal required a study based on scientific investigation, and the students are given the freedom to implement the scientific investigation. One of the learning that is able to achieve this is inquirybased learning. Inquiry-based learning is learning that installs the basics of scientific thinking on students, so that students in the learning process is much more to learn themselves, develop creativity in solving problems. So students actually placed as the subject of learning. 


\section{International Journal of Science and Research (IJSR) \\ ISSN (Online): 2319-7064}

Index Copernicus Value (2013): 6.14 | Impact Factor (2014): 5.611

Inquiry learning allow students mentally and physically through the steps of the scientific method, so that the formation of a scientific attitude in students. This learning allows students to use and develop the ability to think creative when they formulate problems given, experiment, discuss and analyze the evidence, evaluate ideas and expectations, reflecting the validity of the data and the data collection process, consider the conclusion of another friend, to determine how best suggests the discovery and explanation of them, and connect with other people's opinion or developed theories for their conceptual model, Kuslan \& Stone (in Dahar, 1989). Based on the above exposure, the researchers were motivated to develop innovative science learning in the teaching of natural science with methods the implementation of inquiry-based learning to improve understanding the concept of electric dynamic and creative thinking skills on class IX junior high school students state 4 Kendari.

\section{Literature Review}

\section{Inquiry Based Learning}

Jauhar (2011), the inquiries actually comes from the word to inquire which means participating, or are involved in asking questions, searching for information, and conducting investigations. Inquiry can also be interpreted as a process of asking questions and finding out the answers to the scientific questions it proposes. In other words, inquiries is a process for obtaining and get information by observation or experiment to find an answer or solve the problem to a question or problem formulation with the ability to think critically and logically.

In principle objectives of inquiry teaching is to help students learn how to formulate questions, searching for an answer or solution to satisfy curiosity and to develop theories and ideas about the world. National Research Council (2001) the main purposes of inquiry-based learning are: (1) develop the desire and motivation of students to learn the principles and concepts of science; (2) develops the creativity of learners so that they can work like a scientist; (3) familiarize the students to work hard to acquire knowledge. Jauhar (2011), inquiry approach is divided into three levels based on the amount of intervention teacher to the student or the magnitude of the guidance given by the teacher to the students. The third level of inquiry approach is:

1. Guided inquiry approach, guided inquiry approach is an approach to teaching that is trying to lay the groundwork and develop a scientific way of thinking, this approach puts more students learn on their own or as a group to solve the problem given by the teacher.

2. Free inquiry approach, on a general approach used for students who have experienced studying the inquiry approach. Because in this free inquiry approach puts the students as if working as a scientist. Students are given the freedom to determine the issues to be investigated, locate and resolve the problems independently, designing procedures or steps are required.

3. Modified free inquiry approach, this approach is collaboration or a modification of a previous inquiry two approaches, namely: guided inquiry approach and the approach of free inquiry. Even so the problems that made the topic to be investigated still refer to the existing curriculum. That is, in this approach students can't select or specify the issues to be investigated individually, but the students who studied with this approach receives from his teacher to solve the problem and still obtain guidance. Jauhar (2011) stating the stages reached in the implementation of inquiry learning consists of six stages:

1. Orientation, this stage the teacher doing the steps to foster an atmosphere or a conducive learning environment. It is done in the orientation phase are: (1) Describe the topics, objectives and learning outcomes expected to be achieved by students. (2) Explain the main points of the activities to be performed by students to achieve the goal. At this stage of inquiry described the steps as well as the purpose of each step, from formulating a problem to formulate a conclusion. (3) Explain the importance of the topics and learning activities. This is done in order to provide students' motivation.

2. Formulate the problem, is a step in bringing the students on a subject. The issue presented is a question that challenges students to solve.

3. Formulate hypotheses, is temporary answer of a problem being studied. As an interim response, the hypothesis needs to be studied truth. One of the ways that teachers can do to develop the ability to hypothesize on each child is by asking questions that can encourage the students to be able to formulate a response while or can formulate various estimates of possible answers of a problem being studied.

4. Collecting data is to capture the activity of the information needed to test the hypothesis. In inquiry learning, collecting data is a mental process that is very important in the intellectual development. The data collection process not only requires a strong motivation to learn, but also requires persistence and the ability to use the potential of thinking.

5. Test the hypothesis, is determine the answers considered acceptable in accordance with the data or information obtained by data collection. Test the hypothesis also means developing the ability to think rationally. That is, the truth of the answers given not only by argument, but must be supported by the data found and accountable.

6. Formulate conclusions, is a process describes the findings obtained based on the results of hypothesis testing. To reach an accurate conclusion the teacher should be able to demonstrate to students the data where relevant.

\section{Understanding concept and Creative Thinking Skills}

The concept is a thorough idea about the law (principle, the principle) or theories that include a variety of things that are contained in the concept (Darliana, 2008). A concept in terms of epistemological aspects has four essential elements, namely: composition, phenomena, laws, and rules. The concept is all that is tangible new notions that could arise as a result of thought, including the definition, understanding, special features, the essence, the core/ content and so on (Depdiknas, 2006).

Thinking skills are skills that are relatively specific in one's thinking about something that is necessary to understand something of information in the form of ideas, concepts, 


\section{International Journal of Science and Research (IJSR) \\ ISSN (Online): 2319-7064}

Index Copernicus Value (2013): 6.14 | Impact Factor (2014): 5.611

theories, and so on. Knowledge and thinking skills is a union of mutual support. Edward de Bono (2007) suggests that creative thinking is: skill: 1) designing, 2) changes and improvements and 3) get new ideas. McGregor (2007) suggests that the skills of creative thinking associated with "imagination, independence, generatively, maleuticity and inventiveness provide descriptor of valuable characteristics of creative thinking." This definition is more emphasis on the characteristics of creative thinking among them is imagination, experimentation, holism, expression, selftranscendence, shock, generation, and inventiveness.

Liliasari (2005), creative thinking skills are the skills to develop or find an idea or an original idea, aesthetic and constructive, related to views and concepts as well as the emphasis on aspects of thinking intuitive and rational, especially in using information and materials to raise or explain it with the perspective of the original thinker. Khan, \& Iqbal (2011) states that there are two fundamental processes that occur during the process of creative thinking, the cognitive process (what we know), and the non-cognitive (how we feel). Ruseffendi (2004) looked at the skills of creative thinking as a form of cognitive fluidity that supports a person's ability to present symbols. McGregor (2007) suggests there are four aspects of creative thinking skills, namely: (1) generate curiosity and desire to know; (2) establish existing knowledge to students; (3) looking at information from a different angle; and (4) predict from limited information. The relationship of Inquiry learning with an understanding of science concepts that find their own way in the learning process, then the mastery of science concepts will always stick in the memory of the students and not easily forgotten. Science learning will be more meaningful for students when they are active in a variety of ways to construct their own knowledge.

Inquiry learning is a learning approach that can be applied in teaching students in foster creativity in learning and students' critical attitude. Inquiry learning approach prioritizes effective student involvement. Inquiry approach is essentially a social process; students are assisted in performing the role of an observer who is associated with the problems faced. Although the teacher can give the problem situation, but in practice, students seeking, asking, and trying to find their own things that are learned. The students begin to think based on the ability and experience of each logically. Inquiry learning approach put more emphasis on activities cantered on developing creativity in learning and students' critical attitude. Implementation of inquiry learning approach can assist teachers in delivering learning materials to create a variety of learning condition in foster students' motivation to learn more deeply, encourage curiosity further and motivated to think creatively and critically.

Inquiry Learning is learning the basic philosophy of constructivism because, through this learning, students construct their own knowledge. In inquiry learning, students are trained to solve academic problems, increase the understanding of science, and develop learning skills of science and scientific literacy (Germann, 1999). Lawson (2000) suggested the inquiry activity can train students thinking skills and improve skill in solving problems.

\section{Research Method}

This study used a quasi experimental methods and descriptive methods. Quasi experimental method to get an increased understanding of the concepts and creative thinking skills while descriptive methods to get an overview of students' responses to the inquiry-based learning. Experimental research design used was the randomize pretest-posttest control group design (Sugiyono, 2012). At first randomly selected experimental class and control class. Subsequently conducted preliminary tests on two classes, after which both classes are given different treatments and finishes giving the final test with the test device similar to that used in the initial test. The location selected research is junior high school state 4 Kendari. This research was conducted in the first semester of the 2015/ 2016 school year starts from October to November 2015.

The population in this study were all students of class IX semester of academic year 2015/2016, amounting to 10 classes. In this study conducted sampling technique is simple random sampling. Based on the results obtained by random lottery class IX.1 and IX.6 as class experimental group, class IX.1, while and IX.6 as the control group. The procedure consisted of research conducted five steps, namely: literature study, design learning implementation plan and student worksheet, research instruments, research instruments testing, implementation, and concludes with an analysis of the results and preparation of reports.

\section{Results and Discussion}

The results obtained from the implementation of learningbased inquiry for classroom experiments, and conventional learning to control classes on the concept of dynamic power which includes: (1) understanding the concept of the students to the concept of dynamic power, (2) creative thinking skills of students to the concept of dynamic power, (3) the responses of students and teachers on the implementation of inquiry-based learning, and (4) implementation inquiry-based learning. Here will be described the research results and their discussion.

\section{Description Understanding of Concept}

The average scores of initial tests, the final test, and N-gain understanding of the concept of magnetism experimental class and control class can be seen in Figure 1.

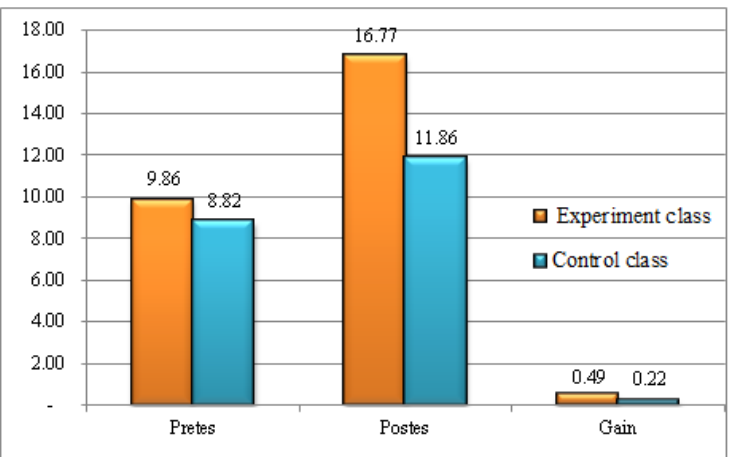

Figure 1: Bar chart comparing the average score pre-test, post-test, and N-gain for understanding the concept of magnetism 


\section{International Journal of Science and Research (IJSR) \\ ISSN (Online): 2319-7064 \\ Index Copernicus Value (2013): 6.14 | Impact Factor (2014): 5.611}

Figure 1 shows the average score of pre-test-grade students experiment at $9.86(41.10 \%)$, and the average score pre-test control class is $8,82(36.74 \%)$, the average score post-test experimental class of 16.77 (69.89\%), and control class reaches 11.86 (49.43\%), N-gain understanding of the concept of experimental class at 0.49 (45.28\%) and for the control class of $0.22(22.05 \%)$. The average $\mathrm{N}$-gain experimental classes including medium category while the average N-gain control classes including low category. Quantity N-gain of the second-class clearly shows the differences increase.

Differences in understanding the concept of every aspect between experimental class and control class can be seen in Figure 2.

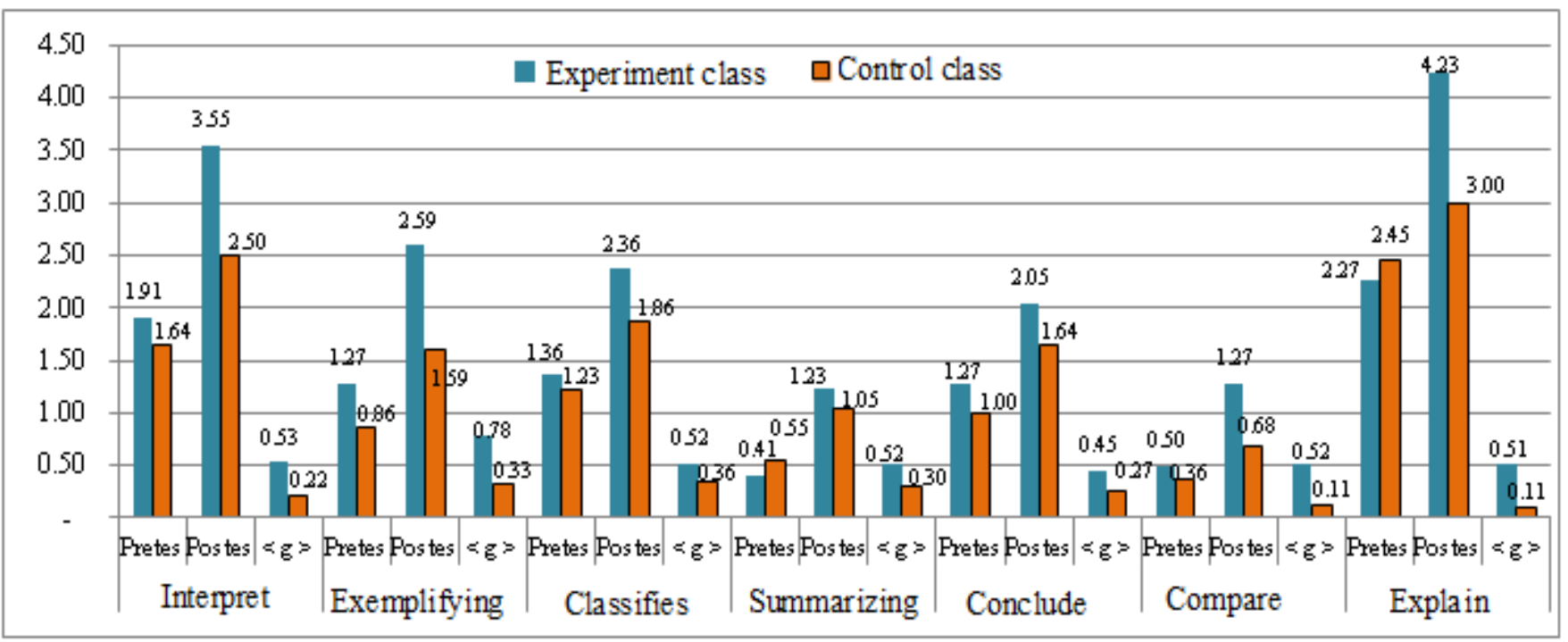

Figure 2: Bar chart comparing the average score pre-test, post-test, and N-gain every aspect of understanding of the concept

Figure 2 indicated that the average score of the average pretest experimental class and control class is relatively similar to interpret aspects, experimental class 1.91 and control class 1.64 , the average score for the experimental class post-test interpret aspects of 3.55, while for the control class 2.50, and the average $\mathrm{N}$-gain on aspects of interpreting for experimental classes reach 0.53 while the control group only reached 0.22 . The average $\mathrm{N}$-gain experimental classes including medium category and control class category still low. However, from the quantity of $\mathrm{N}$-gain shows the differences increase. Furthermore, the average class pre-test score of experimental and control classes on aspects pointed out, the experimental class 1.27 and control class 0.86 , the average score for the experimental class post-test exemplifies aspects of 2.59 while for the control class 1.59, and average $\mathrm{N}$-gain in the aspect pointed to an experimental class of 0.78 , while the control group only reached 0.33 . The average $\mathrm{N}$ gain high experimental class category and grade control is still categorized as low. However, from the quantity of $\mathrm{N}$ gain shows the differences increase.

This research results indicate that the average score of pretest experimental class and control class was relatively similar in the aspect of classifying, the experimental class 1.36 and control class 1.29 , the average post-test score of experimental classes for classifying aspects of 2.36 , whereas for the class Control 1,86, and the average N-gain on aspects of classifying for the experimental class of 0.52 , while the control group only reached 0.36 average $\mathrm{N}$-gain experimental class and the control class including medium category. However, from the quantity of N-gain shows the differences increase. In addition the results of data analysis showed an average score of pre-test experimental class and control class to encapsulate aspects, experimental class 0.41 and control class 0.55 . the average post-test score of experiment class to encapsulate aspects of 1.23 , whereas for the control class 1.05 , and the average score on the $\mathrm{N}$-gain for the experimental class encapsulates aspects of 0.52 , while the control class only reached 0.30 , and the average $\mathrm{N}$-gain experimental classes including medium category and grade control is still categorized as low. However, from the quantity of N-gain shows the differences increase.

The test results pre-test experimental class and control class are relatively similar in aspect to conclude, experimental class 1.27 and control class 1,00, the average score for the experimental class post-test infer aspects of 2.05 while for the control class 1.04, and the average -rata N-gain on aspects concluded for an experimental class of 0.45 while the control class only reached 0.27 and the average $\mathrm{N}$-gain experimental classes including medium category and grade control is still categorized as low. However, from the quantity of $\mathrm{N}$-gain shows the differences increase. Furthermore, the average class pre-test score of experimental and control classes on aspects of comparison, the experimental class 0.50 and control class 0.36 , the average score for the experimental class post-test compare aspects of 1.27 while for the control class 0.68 , and the average $\mathrm{N}$-gain on aspects compared to the experimental class of 0.52 while the control group only reached 0.11 . The average $\mathrm{N}$-gain experimental classes including medium category and grade control is still categorized as low. However, from the quantity of N-gain shows the differences increase.

Finally average pre-test score of experimental classes and control classes are relatively similar in explaining aspects, experimental class 2.27 and control class 2.45, the average score for the experimental class post-test explain aspects 
reached 4.23, while for the control class only 3.00, the average $\mathrm{N}$-gain on aspects of classroom experiments explaining to reach 0.51 , while the control group only reached 0.11 The average $\mathrm{N}$-gain experimental classes including medium category and grade controls including low category. However, from the quantity of N-gain shows the differences increase.

\section{Description Creative Thinking Skills}

The average score pre-test, post-test, and N-gain skills of creative thinking on the concept of magnetism experimental class and control class can be seen in Figure 3.

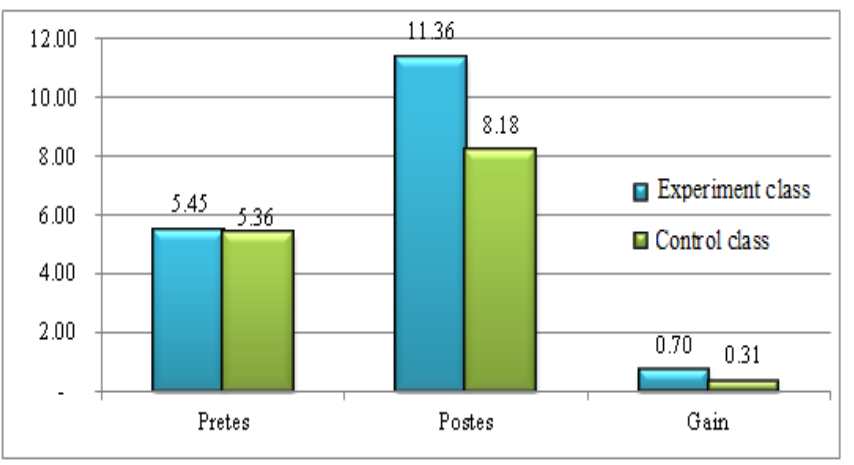

Figure 3: Bar chart comparing the average score pre-test, post-test, and $\mathrm{N}$-gain for creative thinking skills
Figure 3 shows the average score pre-test students are relatively similar, experimental class of 5.45 , and the average score of the initial test control class is 5.36, the average score reached 11,36 post-test experimental class and control class is $8.18, \mathrm{~N}$-gain creative thinking skills experimental class of 0.70 and 0.31 for the control class. The average $\mathrm{N}$-gain high experimental class category whiles the average $\mathrm{N}$-gain control classes including medium category. Quantity N-gain of the second-class clearly shows the differences increase. Differences creative thinking skills of each indicator between experimental class and control class can be seen in Figure 4

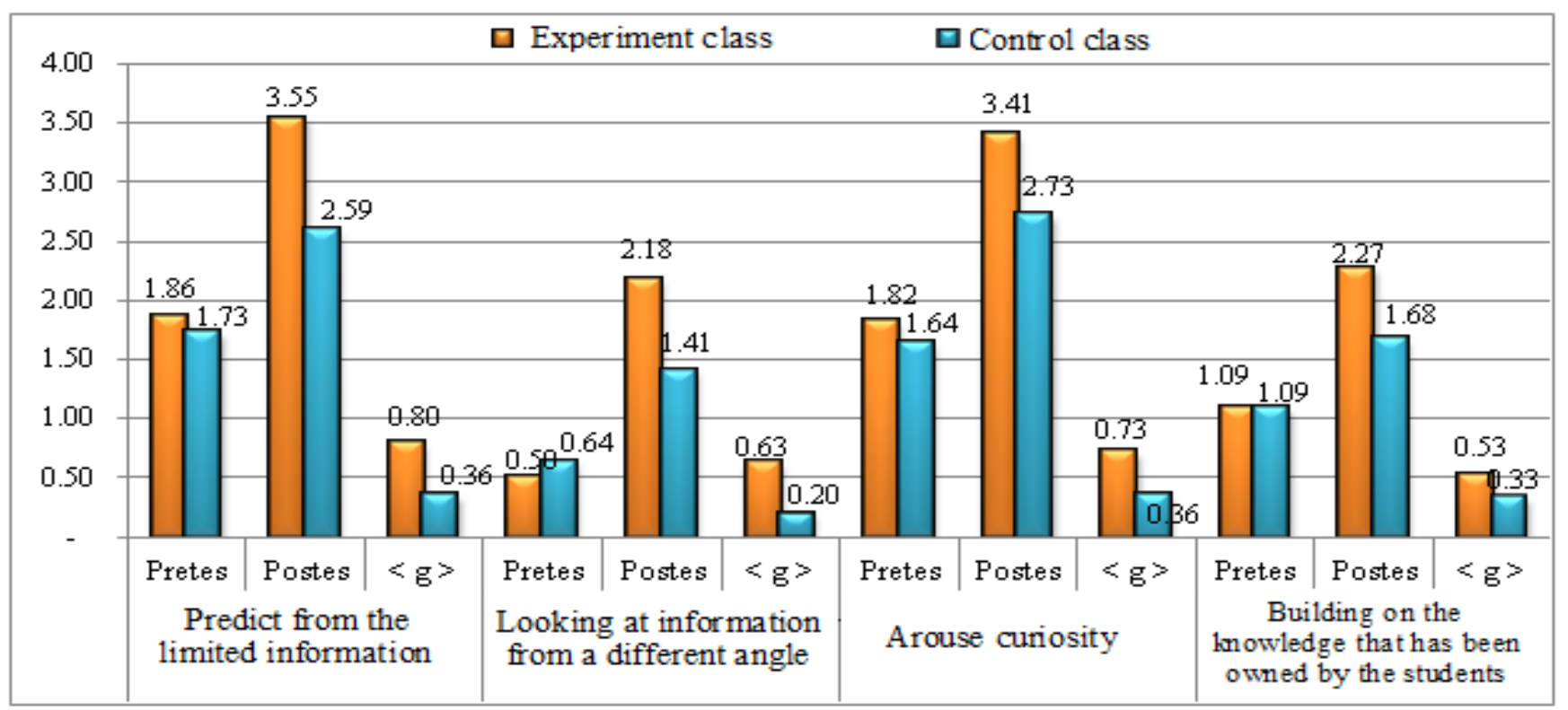

Figure 4: Bar chart comparing the Average Score pre-test, post-test, and N-gain every indicator Creative Thinking Skills

Figure 4 indicated that the fortune-telling indicator of the limited information on average class pre-test score experiment 1.86, and 1.73 control class, relatively the same, the average score of post-test experimental class 3.55(88.64) while for control class 2.59, and the average $\mathrm{N}$-gain experimental classes reach 0,80 while the control group only reached 0.36 . And the average $\mathrm{N}$-gain experimental classes including high category and grade controls including medium category. However, from the quantity of $\mathrm{N}$-gain showed no difference in improvement. Calculation of the average score pre-test, post-test, and N-gain indicators predict different.

\section{Hypothesis testing}

\section{a. Understanding of Concept}

Hypothesis testing is done by using parametric statistics (ttest) and test. This is done if the data both classes normally distributed and has a variance homogeneous test is intended to determine whether the hypothesis can received or rejected and test Mann-Whitney U-test is performed If the data is not normally distributed both classes and have variances that are not homogeneous Testing the hypothesis on the pre-test using t-test is intended to determine whether the students' understanding of concepts in magnetic materials experiment class and control class originated from the same condition. 


\section{International Journal of Science and Research (IJSR) \\ ISSN (Online): 2319-7064 \\ Index Copernicus Value (2013): 6.14 | Impact Factor (2014): 5.611}

The hypotheses to be tested are as follows:

$\mathrm{H}_{0}$ : Not difference significant increase understanding of the concept significantly between the experimental classes students with grade control before the inquiry-based learning.

$\mathrm{H}_{1}$ : There is a difference significant increase understanding of the concept of magnetism significantly between the experimental class students who followed the inquirybased learning than the control class students who follow conventional teaching

Table 1: Results of hypothesis testing understanding of the concept of data

\begin{tabular}{|c|c|c|c|c|c|c|c|c|}
\hline \multirow[b]{2}{*}{ Aspect } & \multicolumn{2}{|c|}{$\begin{array}{c}\text { Class } \\
\text { Experiments }\end{array}$} & \multicolumn{2}{|c|}{$\begin{array}{c}\text { Class } \\
\text { Control } \\
\end{array}$} & \multirow[t]{2}{*}{$\mathrm{S}_{\mathrm{gab}}$} & \multirow[t]{2}{*}{$t_{\text {count }}$} & \multirow{2}{*}{$t_{\text {table }}$} & \multirow[t]{2}{*}{ Result } \\
\hline & $\overrightarrow{\mathrm{X}}_{1}$ & $\mathrm{~S}_{1}^{2}$ & $\overline{\mathrm{X}}_{2}$ & $\mathrm{~S}_{2}^{2}$ & & & & \\
\hline Pretest & 9.86 & 4.49 & 8.82 & 4.81 & 2.23 & 1.550 & & $\begin{array}{c}\mathrm{H}_{0} \text { Received } \\
\text { (Not difference) }\end{array}$ \\
\hline Posttest & 16.77 & 10.56 & 11.86 & 20.03 & 3.91 & 4.190 & 2.021 & $\begin{array}{c}\mathrm{H}_{1} \mathrm{~A} \text { ccepted } \\
\text { (There is a difference) }\end{array}$ \\
\hline $\mathrm{N}$-gain & 0.49 & 0.05 & 0.23 & 0.05 & 0.22 & 3.939 & & $\begin{array}{c}\mathrm{H}_{1} \text { accepted } \\
\text { (There is a difference) }\end{array}$ \\
\hline
\end{tabular}

According to Table 1 for the pre-test obtained $t_{\text {count }}=1.550$ while $t_{\text {table }}=2.021$. This shows that the understanding of the concept of pre-test scores for the two groups did not differ significantly because $t_{\text {count }}<t_{\text {table. }}$. While on the post-test $t_{\text {count }}$ $=4.190$, so $t_{\text {count }}>t_{\text {table, means there are significant }}$ differences. Likewise for the $\mathrm{N}$-gain, from the mean difference test obtained $t_{\text {count }}=3.939$ while $t_{\text {table }}=2.021$. This shows the mean $\mathrm{N}$-gain difference between the two classes, because $t_{\text {count }}>t_{\text {table. }}$. It can be concluded that an improved understanding of the concept of the experimental class is significantly higher than the control class, and it can be said that the use of inquiry-based learning is better than the use of conventional study to improve understanding of the concept.

\section{b. Every Aspect of Understanding of Concept}

Table 2: Results of hypothesis testing every aspect of understanding of the concept

\begin{tabular}{|c|c|c|c|c|c|c|c|c|c|c|}
\hline \multirow[t]{2}{*}{ Aspect } & \multicolumn{2}{|c|}{$\begin{array}{c}\text { Class } \\
\text { Experiments }\end{array}$} & \multicolumn{2}{|c|}{$\begin{array}{l}\text { Class } \\
\text { Control }\end{array}$} & \multirow{2}{*}{$\mathrm{S}_{\mathrm{gab}}$} & \multirow{2}{*}{$\mathrm{U}_{1}$} & \multirow[t]{2}{*}{$\mathrm{U}_{2}$} & \multirow{2}{*}{$\begin{array}{l}\mathrm{t}_{\text {count }} \\
\mathrm{z}_{\text {count }}\end{array}$} & \multirow[t]{2}{*}{ Statistic test } & \multirow[t]{2}{*}{ Result } \\
\hline & & $\mathrm{S}_{1}^{2}$ & $\overline{X_{2}}$ & $\mathrm{~S}_{2}^{2}$ & & & & & & \\
\hline Interpret & 0.53 & 0.17 & 0.22 & 0.05 & 0.33 & - & - & 3.12 & $\begin{array}{c}\mathrm{Ujit} \mathrm{t}_{(0.05 .21)} \\
2.021\end{array}$ & $\begin{array}{l}\mathrm{H}_{1} \text { A ccepted } \\
\text { (There is a } \\
\text { difference) }\end{array}$ \\
\hline Exemplifying & 0.78 & 0.13 & 0.33 & 0.12 & 0.35 & - & - & 4.83 & $\begin{array}{c}\mathrm{Ujit}_{(0.05 .21)} \\
2.021\end{array}$ & $\begin{array}{c}\mathrm{H}_{1} \text { A ccepted } \\
\text { (There is a } \\
\text { difference) }\end{array}$ \\
\hline Classifying & 0.52 & 0.19 & 0.36 & 0.14 & 0.41 & 341 & 440 & 2.32 & $\begin{array}{c}\text { Uji Mann Whitney } \\
\text { Utes }(\mathrm{z}=1.96)\end{array}$ & $\begin{array}{l}\mathrm{H}_{1} \text { A ccepted } \\
\text { (There is a } \\
\text { difference) }\end{array}$ \\
\hline Embrace & 0.52 & 0.19 & 0.30 & 0.16 & 0.42 & 331 & 486 & 2.09 & $\begin{array}{c}\text { Uji Mann Whitney } \\
\text { Utes }(\mathrm{z}=1.96)\end{array}$ & $\begin{array}{c}\mathrm{H}_{1} \text { A ccepted } \\
\text { (There is a } \\
\text { difference) }\end{array}$ \\
\hline Conclude & 0.45 & 0.19 & 0.27 & 0.18 & 0.43 & 322 & 446 & 2.11 & $\begin{array}{c}\text { Uji Mann Whitney } \\
\text { Utes }(\mathrm{z}=1.96)\end{array}$ & $\begin{array}{c}\mathrm{H}_{1} \text { A ccepted } \\
\text { (There is a } \\
\text { difference) }\end{array}$ \\
\hline Compare & 0.52 & 0.23 & 0.11 & 0.31 & 0.52 & - & - & 2.63 & $\begin{array}{c}\mathrm{Uji} \mathrm{t}_{(0.05 .21)} \\
2.021\end{array}$ & $\begin{array}{c}\mathrm{H}_{1} \text { A ccepted } \\
\text { (There is a } \\
\text { difference) }\end{array}$ \\
\hline Explain & 0.51 & 0.12 & 0.11 & 0.20 & 0.40 & - & - & 3.33 & $\begin{array}{c}\mathrm{Uji}_{(0.05 .21)} \\
2.021\end{array}$ & $\begin{array}{c}\mathrm{H}_{1} \text { A ccepted } \\
\text { (There is a } \\
\text { difference) }\end{array}$ \\
\hline
\end{tabular}

Based on the criteria of hypothesis testing for the two parties that using a significance level $\alpha=0.05$ if $t$ count $>t_{\text {table }} \mathrm{H}_{1}$ received value $t_{\text {table }}=2.021$ and to test the two parties with $\alpha$ $=0.05$ is $\mathrm{H}_{\mathrm{o}}$ accepted if $-1.96<\mathrm{z}<1.96$. Statistical test results in Table 5.10 to interpret aspects obtained $\mathrm{t}_{\text {count }}=$ 3.115, while $t_{\text {table }}=2.021$. This shows that there are differences in scores aspect interpret significant improvement, exemplifies aspects obtained $t_{\text {count }}=4.826$, so $t_{\text {count }}>t_{\text {table }}$, means that there are differences in improvement. Significantly, classifying aspects obtained of $\mathrm{z}_{\text {count }}=2.323$ so that $\mathrm{z}_{\text {count }}>1.96$, means there is a significant difference in improvement, obtained by summarizing aspects of $\mathrm{z}$ count $=$ 2,089 so that $\mathrm{z}$ count $>1.96$, means there is a significant difference in improvement, aspects concluded obtained $\mathrm{z}_{\text {count }}$ $=2.113$ so that $\mathrm{z}_{\text {count }}>1.96$, means there is a significant difference in improvement, exemplifies aspects obtained $t_{\text {count }}$ $=2.628$, Likewise to explain aspects obtained $t_{\text {count }}=3.333$. This shows there is a significant difference, because $t_{\text {count }}>$ $t_{\text {table. }}$ It can be concluded that the increase in every aspect of understanding the concept of the experimental class is significantly higher than the control class, and it can be said that the use of inquiry-based learning is better than the use of conventional study to improve understanding of the concept.

\section{c. Creative Thinking Skills}




\section{International Journal of Science and Research (IJSR) \\ ISSN (Online): 2319-7064}

Index Copernicus Value (2013): 6.14 | Impact Factor (2014): 5.611

Table 3: Results of hypothesis testing creative thinking skills

\begin{tabular}{|c|c|c|c|c|c|c|c|c|}
\hline Aspect & $\frac{\text { Expe }}{\overrightarrow{\mathrm{X}}_{1}}$ & $\begin{array}{l}\text { ass } \\
\mathrm{S}_{1}{ }_{1}\end{array}$ & $\begin{array}{l}\mathrm{Co} \\
\overline{\mathrm{X}}_{2}\end{array}$ & $\begin{array}{l}\text { ass } \\
\text { ntrol } \\
S^{2}{ }_{2}\end{array}$ & $S_{g a b}$ & $t_{\text {count }}$ & $t_{\text {table }}$ & Result \\
\hline Pretest & 5.45 & 3.69 & 5.36 & 4.81 & 2.062 & 0.147 & & $\begin{array}{c}\mathrm{H}_{0} \text { Received } \\
\text { (Not difference) }\end{array}$ \\
\hline Posttest & 11.36 & 3.10 & 8.18 & 3.30 & 1.789 & 5.989 & 2.021 & $\begin{array}{c}\mathrm{H}_{1} \mathrm{~A} \text { ccepted } \\
\text { (There is a difference) }\end{array}$ \\
\hline $\mathrm{N}$-gain & 0.70 & 0.04 & 0.31 & 0.03 & 0.187 & 7.605 & & $\begin{array}{c}\mathrm{H}_{1} \text { accepted } \\
\text { (There is a difference) }\end{array}$ \\
\hline
\end{tabular}

Table 3 for the pre-test obtained $t_{\text {count }}=0.147$ while $t_{\text {table }}=$ 2.021. This shows that the understanding of the concept of pre-test scores for the two groups did not differ significantly because $t_{\text {count }}<t_{\text {table, }}$, while at the posttest $t_{\text {count }}=5.989$ so $t_{\text {count }}>t_{\text {table, }}$, means there are significant differences. Likewise for the $\mathrm{N}$-gain, from the mean difference test obtained $\mathrm{t}_{\text {count }}=$ 7.605, while $t_{\text {table }}=2.021$. This shows the mean $\mathrm{N}$-gain difference between the two classes, because $t_{\text {count }}>t_{\text {table }}$. It can be concluded that the increase in the experimental class creative thinking skills significantly higher than the control class, and it can be said that the use of inquiry-based learning is better than the use of conventional learning in improving the skills of creative.

\section{d. Each indicator Creative Thinking Skills}

Table 4: Hypothesis test results of each indicator creative thinking skills

\begin{tabular}{|c|c|c|c|c|c|c|c|c|c|c|}
\hline \multirow{3}{*}{ Aspect } & \multirow{2}{*}{\multicolumn{2}{|c|}{$\begin{array}{c}\text { Class } \\
\text { Experiments }\end{array}$}} & \multirow{2}{*}{\multicolumn{2}{|c|}{$\begin{array}{c}\text { Class } \\
\text { Control }\end{array}$}} & \multirow{3}{*}{$\mathrm{S}_{\mathrm{g} b}$} & \multirow{3}{*}{$\mathrm{U}_{1}$} & \multirow{3}{*}{$\mathrm{U}_{2}$} & \multirow{3}{*}{$\begin{array}{l}t_{\text {covont }} \\
z_{\text {count }}\end{array}$} & \multirow{3}{*}{ Statistic test } & \multirow{3}{*}{ Result } \\
\hline & & & & & & & & & & \\
\hline & $\mathrm{X}$ & $\mathrm{S}^{2}$ & $\overline{X_{2}}$ & $\mathrm{~S}_{2}^{2}$ & & & & & & \\
\hline $\begin{array}{l}\text { Predict from th } \\
\text { limited } \\
\text { information }\end{array}$ & 0.8 & 0.1 & 0.36 & 0.10 & 0.36 & - & - & 4.119 & $\begin{array}{c}\mathrm{Ujit}_{(0.05 .21)} \\
2.021\end{array}$ & $\begin{array}{l}\mathrm{H}_{1} \text { Accepted } \\
\text { (There is a } \\
\text { difference) }\end{array}$ \\
\hline $\begin{array}{l}\text { Looking } \\
\text { information fro } \\
\text { a different angl }\end{array}$ & m 0.6 & 0.2 & 0.20 & 0.41 & 0.56 & - & - & 2.606 & $\begin{array}{c}\mathrm{Uji}_{(0.05 .21)} \\
2.021\end{array}$ & $\begin{array}{l}\mathrm{H}_{1} \text { Accepted } \\
\text { (There is a } \\
\text { difference) }\end{array}$ \\
\hline $\begin{array}{l}\text { A rouse } \\
\text { curiosity }\end{array}$ & 0.7 & 0.0 & 0.36 & 0.38 & 0.47 & - & - & 2.635 & $\begin{array}{c}\text { Uji to.05.21) } \\
2.021\end{array}$ & $\begin{array}{c}\mathrm{H}_{1} \text { Accepted } \\
\text { (There is a } \\
\text { difference) }\end{array}$ \\
\hline $\begin{array}{l}\text { Building on } \\
\text { knowle dge th } \\
\text { has been own } \\
\text { by the students }\end{array}$ & 0.5 & 0.1 & 0.33 & 0.25 & 0.46 & 330 & 426 & 2.065 & $\begin{array}{c}\text { UjiMonn } \\
\text { Whitney Utes } \\
(\mathrm{z}=1.96)\end{array}$ & $\begin{array}{l}\mathrm{H}_{1} \text { Accepted } \\
\text { (There is a } \\
\text { difference) }\end{array}$ \\
\hline
\end{tabular}

Based on the criteria of hypothesis testing for the two parties that using a significance level $\alpha=0.05$ if $t_{\text {count }}>t_{\text {table }} \mathrm{H}_{1}$ received value $t_{\text {table }}=2,021$ and to test the two parties with $\alpha=0.05$ is $H_{0}$ accepted if $-1.96<z<1.96$. Statistical test results in Table 5.12 for fortune telling indicator of the limited information obtained $\mathrm{t}$ count $=4.119$, while $\mathrm{t}_{\text {table }}=$ 2.021. This shows that the indicator scores predict from limited information there are differences significant improvement, the indicators looked at from a different angle obtained $t_{\text {count }}=2.606$, so $t_{\text {count }}>t_{\text {table, means that there are }}$ differences significant improvement, indicator Arouse curiosity obtained $t_{\text {count }}=2.606$, so $t_{\text {count }}>t_{\text {table }}$, means there is a significant difference in improvement, indicator Build knowledge that students have acquired $Z_{\text {count }}=2.323$, so the $\mathrm{Z}_{\text {count }}>1,96$, it indicates there are significant differences. It can be concluded that the increase in each indicator experimental class creative thinking skills significantly higher than the control class, and it can be said that the use of inquiry-based learning is better than the use of conventional learning in improving the skills of creative thinking.
Implementation of Learning

Implementation of Learning on the use of the complete inquiry-based learning can be seen in Table 5 .

Table 5: Implementation of Learning on the use of inquirybased learning

\begin{tabular}{cccccc}
\hline & & \multicolumn{4}{c}{$\begin{array}{c}\text { Achieve ment in } \\
\text { Meetings (\%) }\end{array}$} \\
\cline { 3 - 6 } No. & \multicolumn{1}{c}{ A spects assessed } & I & II & II & IV \\
1. & Learning process & & & & \\
& a. Initial activity & 90 & 100 & 100 & 100 \\
& b. Core activities & 94.2 & 94.2 & 97.2 & 97.2 \\
& c. The activities cover & 90 & 90 & 100 & 100 \\
2. & Learning Resources & 90 & 100 & 100 & 100 \\
3. & Time & 80 & 80 & 80 & 90 \\
Average Percentage (\%) & 88,84 & 92.84 & 95.44 & 97.44 \\
\hline
\end{tabular}

Based on Table 5 can be seen the percentage of each meeting of the feasibility study and the learning process carried out by the teacher can be broken down as follows: feasibility study on the first meeting amounted to $88.84 \%$, in the second meeting amounted to $92.84 \%$, at the third meeting amounted to $95.44 \%$ and the fourth meeting of 97.44 . It can be said that the average percentage of feasibility in terms of the learning process that teachers do during the study by $93.63 \%$.

\section{Student Activity}

Implementation of Learning on the use of the complete inquiry-based learning can be seen in Table 6 .

Table 6: Student activity in learning to use inquiry-based learning

\begin{tabular}{|c|c|c|c|c|c|}
\hline \multirow{2}{*}{ No. } & \multirow{2}{*}{ Aspects assessed } & \multicolumn{4}{|c|}{$\begin{array}{c}\text { Achievement in } \\
\text { Meetings (\%) }\end{array}$} \\
\hline & & I & II & III & IV \\
\hline 1. & Observation & 50 & 70 & 90 & 100 \\
\hline 2. & Formulate the problem & 60 & 80 & 90 & 90 \\
\hline 3. & Develop hypotheses & 60 & 80 & 100 & 100 \\
\hline 4. & Conduct experiments & 70 & 90 & 90 & 100 \\
\hline & Collecting data & 50 & 70 & 90 & 100 \\
\hline 6. & Analyzing the data & 50 & 100 & 80 & 100 \\
\hline 7. & Conchusion & 50 & 80 & 100 & 100 \\
\hline 8. & Application results conclusions & 60 & 80 & 90 & 90 \\
\hline 9. & Presentation of the results of activities & 50 & 70 & 80 & 100 \\
\hline 10. & Treatment irrelevant & 50 & 40 & 30 & 20 \\
\hline & Average Percentage (\%) & 55 & 70 & 84 & 90 \\
\hline
\end{tabular}

Table 6 shows that the percentage of student activity conducted in each meeting learning can be broken down as follows: activity at the first meeting by $55 \%$, in the second meeting by $70 \%$, in the third meeting of $84 \%$, and at the fourth meeting of 90 . So it can be said that the average percentage of student activity in terms of the learning process that teachers do during the study by $76.25 \%$.

\section{Response of Students}

The response of students to the use of the complete inquirybased learning can be seen in Table 7 . 


\section{International Journal of Science and Research (IJSR) \\ ISSN (Online): 2319-7064}

Index Copernicus Value (2013): 6.14 | Impact Factor (2014): 5.611

Table 7: The response of students to the use inquiry-based learning

\begin{tabular}{|c|c|c|c|c|}
\hline \multirow{2}{*}{ No } & \multirow{2}{*}{ Question } & \multicolumn{2}{|c|}{ Average } & \multirow{2}{*}{ Criteria } \\
\hline & & Score & Response (\%) & \\
\hline 1. & Learning magnetism with inquiry-based leaming fun & 4.4 & 88.2 & A gree \\
\hline 2. & $\begin{array}{l}\text { Learning magnetism with inquiry-based learning motivates me to } \\
\text { dig further information }\end{array}$ & 4.3 & 85.5 & A gree \\
\hline 3. & $\begin{array}{l}\text { Learn about the concept of magnetism using berbasiss inquiry } \\
\text { learning can gain a real learning experience }\end{array}$ & 4.4 & 87.3 & A gree \\
\hline 4. & $\begin{array}{l}\text { Studying the concept of magnetism with inquiry-based learning } \\
\text { helps to me to understand the concepts being studied }\end{array}$ & 4.3 & 86.4 & A gree \\
\hline 5. & $\begin{array}{l}\text { Learning the concepts of physics by inquiry-based learning makes } \\
\text { me interested to learn more about physics }\end{array}$ & 4.6 & 91.8 & A gree \\
\hline 6. & $\begin{array}{l}\text { Learning to use inquiry-based leaming is encouraged me to find } \\
\text { their own concepts and principles on the material being studied }\end{array}$ & 4.5 & 89.1 & A gree \\
\hline 7. & $\begin{array}{l}\text { Learning materials magnetism with inquiry-based leaming to } \\
\text { develop my creative thinking skills }\end{array}$ & 4.5 & 89.1 & A gree \\
\hline 8 & $\begin{array}{l}\text { With inquiry-based learning material that is taught to be more } \\
\text { easily understood }\end{array}$ & 4.5 & 89.1 & A gree \\
\hline 9 & $\begin{array}{l}\text { Questions contained in the student activity sheet to help smooth the } \\
\text { experiments conducted to construct and find the concepts leamed. }\end{array}$ & 4.2 & 84.5 & A gree \\
\hline 10 & This inquiry-based leaming objectives clear and focused & 4,6 & 91.8 & A gree \\
\hline
\end{tabular}

The following discussion of the results of the study is based on analysis of the data and findings in the field. Furthermore, to contribute towards the improvement when using this learning, need to put forward things that support the success of the learning process of Physics, especially the concept of magnetism.

Differences in the ability of students to answer the question of understanding the concept occurs in the experimental class and control class. N-gain in the experimental class 0,49 (Medium criteria) while the control group of 0,22 (low criteria). Of the quantity of $\mathrm{N}$-gain both classes show differences in an increased understanding of the concept. Then statistically tested differences in understanding of concepts based aspects. The results show that there are differences in understanding the concept of a significant increase in the use of inquiry-based learning with conventional learning. Thus the inquiry-based learning has been able to increase the understanding of the concept in every aspect.

Differences in the ability of students to answer about creative thinking skills occur in the experimental class and control class. N-gain in the experimental class of 0.70 (high criteria), while the control class by 0.31 (medium criteria). Of the quantity of $\mathrm{N}$-gain both classes show differences increase creative thinking skills. Then statistically tested differences in creative thinking skills based on indicators. The results show that there are differences in creative thinking skills upgrading any significant indicator among students who take the inquiry-based learning and students who take conventional learning.

\section{Conclusion}

Based on the results of research and discussion in the previous chapter, it can be deduced: (1) inquiry-based learning can further improve the understanding of the concept and creative thinking skills of students than learning using conventional learning; (2) exist difference significant increase in understanding of the concept among the students who take the inquiry-based learning and students who take conventional learning; (3) exist differences creative thinking skills increase significantly between students who take the inquiry-based learning and students who take conventional learning; and (4) student responses to the instructional use of inquiry-based learning on the concept of magnetism give a positive response (agree), and students feel the benefits of matter physics in everyday life and is easy to understand the concept.

Research has been done still has many shortcomings, for the researchers suggest the following: (1) in the process of learning in the classroom, teachers should carry out the inquiry learning; (2) in implementing inquiry-based learning teachers should provide clues as clear as possible to the activities to be carried out; (3) inquiry-based learning requires a long time so, teachers should manage time well; and (4) to enrich the data on inquiry-based learning in improving the understanding of concepts and creative thinking skills, it is necessary to study the different materials. 


\section{References}

[1] Chin, C \& Chia, (2005). Problem-based learning: Using ill-structured problem in biology project work. Science Education.Vol 90 (1), pp 44-67

[2] Dahar R.W., (1996). Learning theories. Bandung: Erland.

[3] Darliana, (2008) Analysis of Objects and Phenomena of Physics Junior and Learning was. Bandung: PMPTKP4TKIPA

[4] Jauhar, M., (2011) Implementation PAIKEM of Behavioristik to Konstruktivistik a Development-Based Learning (CTL). Jakarta: Achievements Library Publisher

[5] Keefer, R., (1999). Criteria for Designing Inquiry Activities that Are Effective for Teaching and Learning Science Concepts.Journal College Science Teacher.

[6] Khan, M., \& Iqbal, M. Z (2011) Effect of inkuiri lab teaching Method on the development of scientific skills through the teaching of biology in Pakistan. Strength for today and bright hope for tomorrow journal.

[7] Lawson, A. E., (2000). The Generality of HypoteticoDeductive Reasoning: Making Scientific Thinking Explicit.The American Biology Teacher.

[8] Liliasari, (2005). Building the Indonesia Human Thinking Skills Through Science Education. Inauguration Speech Remains in science education IPA. Indonesian education university.

[9] McBride, J.W, (2004) Using an inquiry approach to teach science to secondary school science teachers. IOP Publishing LTD. In Physics Education [Online], Vol. 39 (5), pp 1-6

[10] McGregor, (2007). Developing Thinking; developing learning a Guide to Thinking Skill in Education. Enggland. McGraw Hill.

[11] Ministry of Education [Depdiknas] (2006). Candy Diknas No. 22 on the Content Standards. Jakarta: Ministry of Education.

[12] Sanjaya, Vienna, (2011) Learning Strategies Oriented Processing Standards Education. Jakarta: Kencana Prenada Media.

[13] Sugiyono, (2008) Quantitative Research Methods, Qualitative and R \& D. Bandung: CV Alfabeta. 